\title{
Design of a Simulated Experimental Apparatus of Electric Automobile Gong Wenzi
}

College of Automobile Engineering, Wuxi Institute of Commerce, Wuxi, Jiangsu ,China, 214153

email:gongwenzi1968@sina.com

Keywords: Electric automobile; Power system; Simulated experimental apparatus; Overall scheme design

\begin{abstract}
This paper introduces a kind of experimental apparatus based on the basic structure and working principle of electric automobile power system. The experimental apparatus is integrated with power system's power battery, controller, DC/DC conversion module, permanent magnet brushless DC motor, motor encoder, temperature sensor and instrument, and can demonstrate the basic components, circuit connection, energy transfer and driving modes of electric automobile power system, convenient for teachers to teach and students to learn.
\end{abstract}

\section{Introduction}

Automobile industry is one of the important pillar industries of national economy, and also reflects national competitiveness as a landmark industry. At present, China has become the world's largest country of auto production and sales, and the resulting energy security and environment problems become increasingly prominent; thus, vigorously developing electric automobiles and accelerating the industrialization process of electric automobiles become a necessary choice for responding effectively to energy and environmental challenges and for realizing the sustainable development of China's automobile industry, and are also important actions to grasp strategic opportunities, shorten the gap with advanced countries, and achieve the leap development of automobile industry [1-2]. It can be anticipated that in the next few years, the automobile after-market will be dire to lack of high quality and skilled talents mainly with relevant knowledge of electric automobiles. Higher vocational colleges training high-skilled talents should comply with the demands of enterprises and market, speed up the cultivation of electric automobile technology application talents, and strengthen the construction of relevant training equipment and training rooms, to meet the social demands for talents in the future. However, as the electric automobile prices are high, owing to the lack of technical data, the development of experimental apparatus is involved in certain difficulty; and the power battery voltage is high and has certain potential safety hazards. Therefore, it is of very important significance to develop a safe, economic and intuitive electric automobile experimental apparatus with good interactivity convenient and simple to operate.

\section{Overall Scheme of the Experimental Apparatus}

For this experimental apparatus, according to the basic working principle of typical electric automobile power system, the electric automobile power system's power battery, controller, DC/DC conversion module, permanent magnet brushless DC motor, motor encoder and temperature sensor ("permanent magnet brushless DC motor" and "motor encoder and temperature sensor" mounted together), instrument and other major components are integrated on one platform, which can directly show the working process and operating parameters of the electric automobile power system under working conditions.

The control principle of the experimental apparatus is shown in Figure 1. This experimental apparatus is composed of power supply, sensor, controller, motor, display instrument and auxiliary devices and the functions of its main parts are shown in Table 1. 


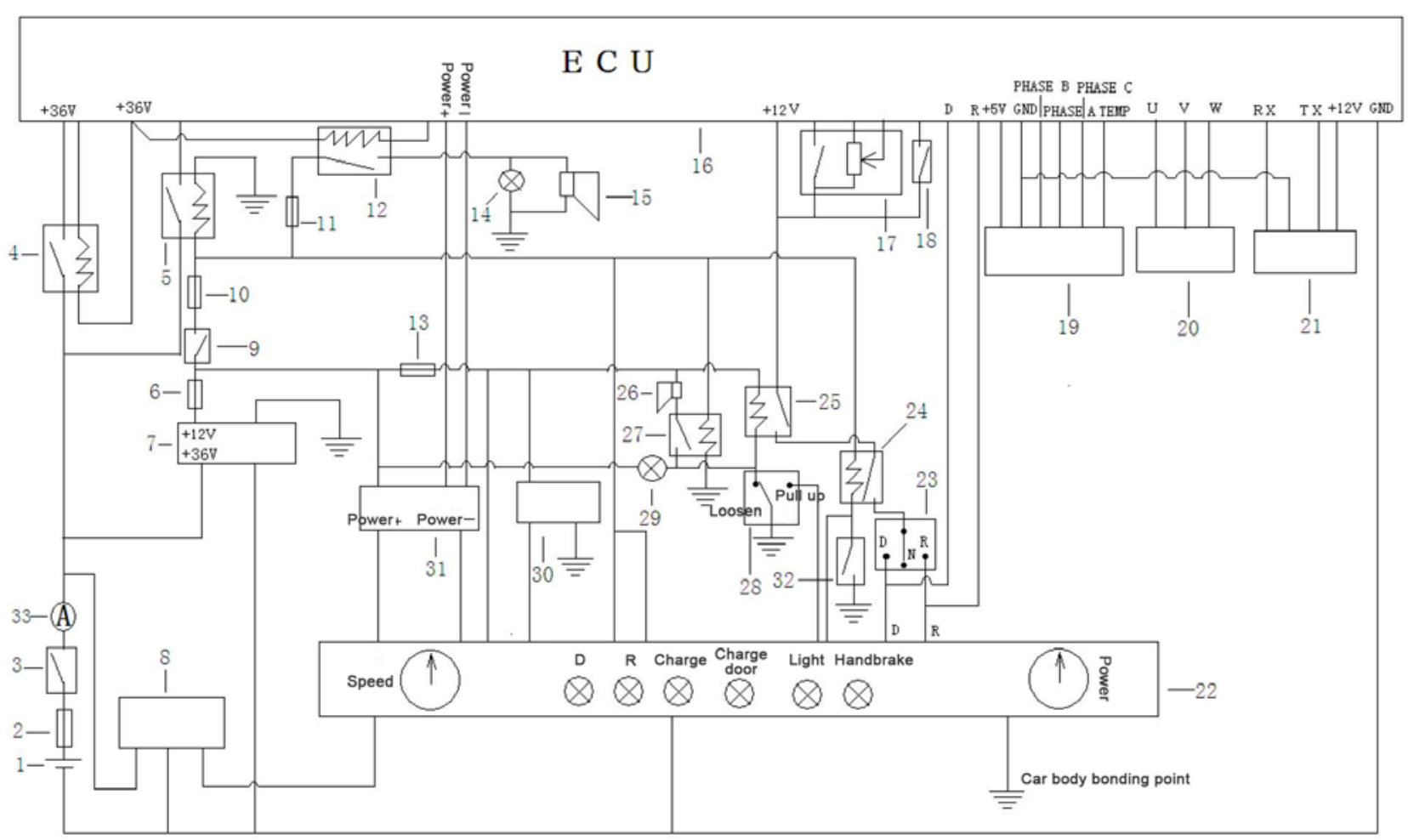

Fig.1 Control principle diagram

1- power battery (36V); 2-master fuse; 3- power master switch; 4-main contactor; 5- main relay; 6- DC/DC output fuse; 7-DC/DC converter module; 8- charging interface; 9- ignition switch; 10-ignition fuse; 11-reversal fuse; 12reversal relay; 13 - instrument fuse; 14 - reversing lamp; 15- reversing thumper; 16- controller; 17- accelerator pedal switch and position sensor; 18- brake switch; 19-motor encoder and temperature sensor; 20-permanent magnet brushless DC motor; 21- programmer interface; 22 - instrument assembly; 23-gear switch; 24-charging protection relay; 25- handbrake protection relay; 26-handbrake thumper; 27- handbrake alarm relay; 28 -handbrake status switch; 29 -handbrake status indicator light; 31-speed sensor; 30-battery isolator; 32-charging protection switch (the switch is closed when the valve is open); 33-current meter

\section{Working Principle and Working Process of the Experimental Apparatus}

The experimental apparatus is operated following these steps below under the condition of good installation and wiring, and its working principle and working process will be completely shown [5-6].

(1) Close the master power switch 3, and DC/DC converter module 7 converts $36 \mathrm{~V}$ into $12 \mathrm{~V}$ output.

(2) Close the ignition switch 9, and the light of the instrument assembly 22 is on; the main relay 5 is closed and the main contactor 4 is closed, and the electricity meter of the instrument assembly 22 displays power value.

(3) Loosen the handbrake (handbrake status switch 28), and the handbrake status indicator light 29 is on, the handbrake protection relay 25 is closed; the gear switch 23 is connected to $\mathrm{D}$, and the $\mathrm{D}$ indicator light of the instrument assembly 22 is on; after stepping down the accelerator pedal switch and position sensor 17, the permanent magnet brushless DC motor 20 rotates positively, the speedometer of the instrument assembly 22 shows the speed and the current meter 33 shows the discharging state; the bigger the stepped accelerator pedal stroke, the higher the permanent magnet brushless DC motor 20 speed and the bigger discharge current shown by the current meter 33 .

(4) If the motor rotates, step down the brake to stop the motor, then connect the gear switch 23 to $\mathrm{R}$, and the $\mathrm{R}$ indicator light of the instrument assembly 22 is on, the reversing relay 12 is closed, the reversing indicator light 14 is on and the reversing thumper 15 sounds to alarm; after stepping down the accelerator pedal switch and position sensor 17, the permanent magnet brushless DC motor 20 rotates reversely, the speedometer of the instrument assembly 22 shows the speed, and the current meter 33 shows the discharging state; the bigger the stepped accelerator pedal stroke, the higher the 
permanent magnet brushless DC motor 20 speed and the bigger discharge current shown by the current meter 33.

Table 1 Functions of main parts [3-4]

\begin{tabular}{|c|c|c|}
\hline No. & Part Name & Function \\
\hline 1 & Power battery 1 & $\begin{array}{l}\text { The entire apparatus is provided with a working power supply. It is } \\
\text { composed of three pieces of } 12 \mathrm{~V} \text { storage batteries in series, and the voltage } \\
\text { of series batteries is } 36 \mathrm{~V} \text {, within the scope of safety voltage. }\end{array}$ \\
\hline 2 & Main contactor & $\begin{array}{l}\text { Normally open relay, used to control the electric power system power } \\
\text { supply. }\end{array}$ \\
\hline 3 & $\begin{array}{l}\text { Main relay } 5 \text {, reversing } \\
\text { relay } 12 \text {, handbrake } \\
\text { protection relay } 25\end{array}$ & Normally open relay, used to control. \\
\hline 4 & $\begin{array}{l}\text { DC/DC conversion } \\
\text { module } 7\end{array}$ & $\begin{array}{l}\text { Convert 36V DC power of the batteries into } 12 \mathrm{~V} \text { direct current, for regular } \\
\text { electrical power supply. }\end{array}$ \\
\hline 5 & Charging interface 8 & $\begin{array}{l}\text { Connected to external 220V AC power supply to charge and when charging, } \\
\text { the charging indicator light on the instrument is on. }\end{array}$ \\
\hline 6 & Controller 16 & $\begin{array}{l}\text { Receive and process a variety of external input signals, and control the } \\
\text { motor speed and direction in accordance with the scheduled program; with } \\
\text { the function of energy recovery, reversely charge the power battery under } \\
\text { certain conditions; and provide the instrument with electric signal of power } \\
\text { battery through electric sensors. }\end{array}$ \\
\hline 7 & $\begin{array}{l}\text { Accelerator pedal } \\
\text { switch and position } \\
\text { sensor } 17\end{array}$ & $\begin{array}{l}\text { Provide the controller with the signal about whether to step on the } \\
\text { accelerator and the extent of stepping. }\end{array}$ \\
\hline 8 & Brake switch 18 & Provide the controller with braking signal \\
\hline 9 & $\begin{array}{l}\text { Motor encoder and } \\
\text { temperature sensor } 19\end{array}$ & Provide the controller with motor rotor position and temperature signal. \\
\hline 10 & $\begin{array}{l}\text { Permanent magnet } \\
\text { brushless DC motor } 20\end{array}$ & $\begin{array}{l}\text { Controlled by the controller 16, the motor direction and speed are controlled } \\
\text { by the control phase sequence and frequency; the controller } 16 \text { can also } \\
\text { control the motor in the mode of power generation, and part of the vehicle's } \\
\text { kinetic energy is converted into electrical energy, namely "energy } \\
\text { recovery". }\end{array}$ \\
\hline 11 & $\begin{array}{l}\text { Programmer interface } \\
21\end{array}$ & $\begin{array}{l}\text { A fault diagnostic instrument can be connected to read the fault code and } \\
\text { data flow and the parameters can be set. }\end{array}$ \\
\hline 12 & $\begin{array}{l}\text { Instrument assembly } \\
22\end{array}$ & $\begin{array}{l}\text { It can display speed, electric quantity, gear, charging, handbrake, and } \\
\text { charging valve status. }\end{array}$ \\
\hline 13 & Gear switch 23 & Provide the controller with gear information. \\
\hline 14 & $\begin{array}{l}\text { Charging protection } \\
\text { relay 24, handbrake } \\
\text { alarm relay } 27\end{array}$ & Normally closed relay, used to control. \\
\hline 15 & $\begin{array}{l}\text { Handbrake status } \\
\text { switch } 28\end{array}$ & Simulate the handbrake "loosen, pull up" state. \\
\hline 16 & Speed sensor 30 & Provide the instrument assembly with speed signal \\
\hline 17 & Battery isolator 31 & $\begin{array}{l}\text { Isolate the power battery signals provided by the controller and convert into } \\
\text { electric quantity signal of the instrument system, used for the instrument } \\
\text { system to display the electric quantity information of power battery. }\end{array}$ \\
\hline 18 & Current meter 33 & Display the power battery involved in the charging or discharging status. \\
\hline
\end{tabular}

(5) When the charging valve is open and the charging protection switch 32 is closed, the charging indicator light of the instrument assembly 22 is on, the charging protection relay 24 is open, and the power supply of the gear switch 23 is disconnected, so the apparatus cannot be driven, failing in safety protection.

(6) When charging (the charging valve is open, the charging interface is connected to an external charger, the master power switch 3 is closed, but the ignition switch 9 is not closed), the charging indicator light of the instrument assembly 22 is on and the current meter 33 shows the charging status.

(7) Shut down (disconnect) the ignition switch 9, and if the handbrake status switch 28 is in the "loose" state, the handbrake status indicator light 29 is on and the handbrake thumper 26 sounds to 
alarm, reminding not forgetting to pull the handbrake.

(8) When the master power switch 3 is closed, and the handbrake switch 28 is in a state of "pull up", the handbrake indicator light of the instrument assembly 22 will be on.

(9) When the speed is high (such as higher than $120 \mathrm{~km} / \mathrm{h}$ ), or stepping on the brake (i.e., the brake switch 18 is closed), the permanent magnet brushless DC motor 20 is in the mode of power generation to charge the power battery 1 , and the current meter 33 shows the charging status.

\section{Conclusion}

This experimental apparatus can directly demonstrate the composition, circuit connection, energy transfer, running condition and other contents of electric automobile power system, so that students have a more intuitive understanding of the composition and working principle of electric automobile power system. The experimental apparatus developed based on this circuit can be used for fault setting, real-time detection, and remote control operation. It is very convenient to debug and detect the experimental apparatus, and the experimental apparatus is secure, economic, and environmental protection. The experimental apparatus can also be developed, designed and produced by the students under the guidance of teachers in the form of project, thus to improve students' comprehensive ability to use knowledge, and capability of science and technology innovation.

\section{References}

[1] Chen Liuqin. Development of new energy automobile industry in our country and its dilemma [J]. Journal of Zhengzhou Institute of Aeronautical Industry Management, 2011 (3): 18 to 25.

[2] Chen Liuqin. Policy support for development of new-energy automobile industry [J]. Journal of Nantong University (social science edition), 2010, 26 (4): 124-133.

[3] Zou Zhengyao, Wang Ruoping. New energy automotive technology [M]. Beijing: National Defence Industry Press, 2012.

[4] Zhao Hang. Hybrid electric automobile technology [M]. Beijing: China Machine Press, 2012.

[5] He Hongwen etc. Principle and structure of electric automobile [M]. Beijing: China Machine Press, 2012.

[6] Zhao Lijun Tong Qinzhi. Structure and principle of electric automobile [M]. Beijing: Peking University Press, 2012. 